\title{
圧電素子によるエネルギ回収を利用した CFRP はり構造の準能動的制振*1 Semi-Active Vibration Control of CFRP Beam Structures Using Piezoelectric Energy Harvesting
}

\author{
亀 山正 樹*2 ·高 栁 宜 孝*2 ·福 永 久 雄 $* 2$ \\ Masaki Kameyama, Nobutaka TAKayanagi and Hisao Fukunaga
}

Key Words : Vibration Control, Semi-Active Control, Energy Harvesting, Piezoelectric Transducer, Composite Materials

\begin{abstract}
The present paper treats a semi-active vibration control based on a synchronized switch damping (SSD) technique. To enhance the performance of semi-active vibration control method, the piezoelectric energy harvesting techniques are adopted instead of constant voltage sources in SSD on voltage sources (SSDV). This harvesting technique exploits the property of piezoelectric vibration to electricity converters, and requires no external voltage source. An experimental verification of the present vibration suppression method named as a synchronized switch damping on piezoelectric energy harvesters (SSDP) for CFRP cantilevered beams is carried out. The experimental results show that the proposed vibration control method is effective for vibration suppression of composite structures as well as SSDV technique. It is also shown that there exist threshold values of generated voltage of the piezoelectric element and excitation frequency of the cantilevered beam in energy harvesting device for achieving stable control effect based on the present method.
\end{abstract}

1. 緒 言

近年，圧電素子を用いた構造物の能動的，あるいは受動 的な振動制御に関する研究・開発が活発に行われている11. 能動制御に基づく制振 $\left.{ }^{2}\right)$ は, 制振能力が高いものの構造物 に外部から電気エネルギを注入して制振を行うことからそ のエネルギが発散振動に繋がる可能性があり, 安定性の面 において問題がある。また，太陽エネルギ以外に電力の供 給が困難な宇宙空間での利用を想定した場合, 複雑な制御 則や大きな外部電力が必要であることは大きな欠点となる. 一方，受動制御に基づく制振 3,4$)$ では，抵抗・コイル等に より構成される簡単な電気回路（シャント回路）を圧電素 子に接続することにより, 外部電力を全く用いることなく 減衰付加を達成できるが，高い制振効果を得るためには広 大な圧電素子の貼付面積や非常に大きなインダクタンス值 を有するコイルが必要となること, 等の問題がある。また, 依然としてモデル化誤差等に伴う制振能力の低下が著しく, 実用性の面において問題がある.

そこで近年提案されている制振方法が，能動制御，受動制 御, 各々が有する欠点を軽減, もしくは解消する中間的な方 法としての準能動制御に基づく制振である. 準能動制御に 基づく制振は, 系のパラメータを積極的に制御することに よって系固有の受動的制振能力が最大限に発揮できるよう にするものであり, Clark $^{5)}$ によって圧電素子の開放時と短

\footnotetext{
*1 (C) 2010 日本航空宇宙学会

平成 22 年 4 月 7 日原稿受付

*2 東北大学大学院工学研究科航空宇宙工学専攻
}

絡時の剛性の違いを利用して制振を行えることが指摘され て以来, 非常に注目されている. 本研究で取り扱う Richard ら 6,7) が提案した同調スイッチダンピング (Synchronized Switch Damping; SSD）と呼ばれる制振方法は，R 回路 (SSD on Short circuit; SSDS) やLR 回路 (SSD on Inductor; SSDI）にスイッチを組み込み，回路の開放・短絡 を瞬間的に切り替えることによって構造物から振動エネル ギを回収・散逸し, 制振を行うものである. 構造物に外部工 ネルギを注入しないことから系は絶対安定であり, 能動制 御に基づく制振に比べて必要とされる外部電力を大幅に削 減できる。また, 積極的なエネルギの散逸によって受動制 御に基づく制振よりも優れた制振効果を得ることができる, 等多くの利点を有するため, SSD に基づく制振に関する研 究は数多く行われている8,9). 近年では, 準能動制御に基づ く制振の制振効果を向上する方法として, SSD に定電圧源 を組み合わせた SSDV (SSD on Voltage sources)10〜12) と 呼ばれる方法が提案されている. SSDVでは, 外部エネル ギの注入による系の不安定化に関する問題が生じるものの, 制御方法自体は準能動制御に基づいているため, 能動制御 に基づく制振と比較してより効率的に制振効果が得られる ことが報告されている.

以上のように, 準能動制御に基づいた振動エネルギの積 極的な散逸による制振には多くの利点があり, その発展型 である SSDVは制振効果のさらなる向上を可能とするもの の, 定電圧源を必要とすることは, 限られた電力しか得ら れない宇宙空間における適用を検討する場合には大きな問 題となる. 
そこで, 本研究では, 振動制御対象となる構造体とは別に 制御対象ではない振動源となる構造体が存在する場合を考 え，SSDV に基づく構造物の制振方法を基礎に，SSDVに おける外部電源の代替として圧電エネルギ回収機（Piezoelectric Energy Harvester）を用い, 構造物の駆動部等の 振動源における微小な定常振動エネルギから変換された電 気エネルギを振動制御に即時利用することにより，外部電 源を別途用いることなく準能動制御に基づく制振の制振効 果を向上させる方法を提案する。

本論文の構成は次の通りである，初めに，圧電素子によ るエネルギ回収に関して概説するとともに，振動する構造 物から回収される電圧とその蓄電速度について定式化を行 う。また，本研究で提案する制振方法の基礎となる SSDV に関して概説するとともに，圧電素子を含む構造物の等価 モデルに拉ける制振効果に関して定式化を行う. 次に, 本研 究で提案する圧電エネルギ回収機による同調スイッチダン ピング (Synchronized Switch Damping on Piezoelectric energy harvesters; SSDP) に基づく制振方法の概要を述べ るとともに，定常振動するCFRP 片持はりを対象とした振 動制御実験を行う。実験により得られた結果を通して, 圧 電素子によるエネルギ回収特性を踏まえ本提案方法の特性 について考察を行うとともに，本方法の有効性を検証する．

\section{2. 定式化}

本研究では，振動制御対象となる構造体とは別に制御対象 ではない振動源となる構造体が存在する場合を考え, SSDV に基づく構造物の制振方法を基礎に，SSDVに拀ける外部 電源の代替として圧電素子によるエネルギ回収技術を適用 した準能動的制振方法に関する検討を行う。本章では, 圧 電素子によるエネルギ回収，およびSSDV に基づく制振に 関する定式化を行う。

2.1 エネルギ回収 本提案方法ではエネルギ回収によっ て得られる電荷を振動制御に即時利用するため, その電荷 量を定量的に評価することが必要となる，本節では，初め に圧電素子によるエネルギ回収の概要を述べ, 定常振動す る構造物に貼付した圧電素子によって蓄えられる電圧, お よびその蓄電速度に関して定式化を行う。

2.1.1 収束蓄電圧に関する定式化 共振点付近で線形振 動する構造物は, 圧電素子を含め, 第 1 図に示すような 1 自由度系の等価モデルとして表される。図中， $M, C, K$ はそれぞれ, 質量, 減衰, 剛性倸数であり，F は外力であ る.また，本研究で適用される圧電エネルギ回収機は，第 2 図に示すように，振動する構造物に貼付した圧電素子，ダ イオードブリッジ, 蓄電コンデンサ (静電容量 $\left.C_{r}\right)$, およ び抵抗（抵抗值 $R_{r}$ ) から構成され, 外部エネルギを一切 必要とせずに振動エネルギから電気エネルギを取り出すこ とができる。ここで, 第 2 図に扔いて, 圧電素子はコンデ ンサ ( 静電容量 $\left.C_{P}^{S}\right)$, および圧電効果により生じる電圧の 発生器 $V_{a}$ によってモデル化されている. 圧電素子に生じ る力 $F_{P}$, 変位 $u$, 電圧 $V_{P}$, および電流 $I\left(=\mathrm{d} Q_{P} / \mathrm{d} t\right)$ の関係を表す圧電方程式は次式で与えられる ${ }^{13)}$.

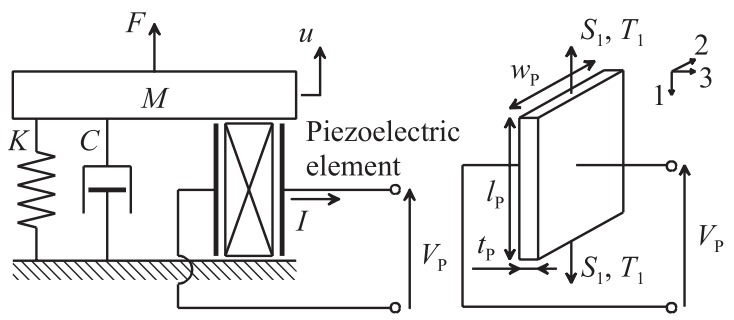

第 1 図 圧電素子を有する 1 自由度系モデル

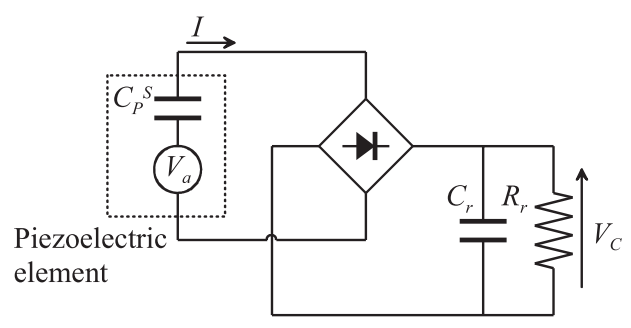

第 2 図 圧電素子を用いたエネルギ回収

$$
\left\{\begin{array}{c}
F_{P} \\
I
\end{array}\right\}=\left[\begin{array}{cc}
K_{P E} & \Theta \\
\Theta \frac{\mathrm{d}}{\mathrm{d} t} & -C_{P}^{S} \frac{\mathrm{d}}{\mathrm{d} t}
\end{array}\right]\left\{\begin{array}{c}
u \\
V_{P}
\end{array}\right\}
$$

ここで, $K_{P E}, C_{P}^{S}$, および $\Theta$ はそれぞれ, 回路短絡時の 圧電素子の剛性, 圧電素子の拘束静電容量, および圧電力 係数を表し, 分極方向を 3 軸方向とし, 1 軸方向の応力 $T_{1}$, ひずみ $S_{1}$ のみを考慮する場合に次式で定義される。

$$
\left(\begin{array}{lll}
K_{P E} & C_{P}^{S} & \Theta
\end{array}\right)=\left(\frac{1}{s_{11}^{E}} \frac{w_{P} t_{P}}{l_{P}} \varepsilon_{33}^{S} \frac{l_{P} w_{P}}{t_{P}} \frac{d_{31}}{s_{11}^{E}} w_{P}\right)
$$

なお， $s_{11}^{E}$ は圧電素子 $\left(\right.$ 寸法 $\left.l_{P} \times w_{P} \times t_{P}\right)$ の回路短絡時 における弾性コンプライアンス, $\varepsilon_{33}^{S}$ は拘束誘電率, $d_{31}$ は 圧電ひずみ定数を表す。

本研究では，圧電素子を貼付した片持はりに対して外部 から周期加振力を加えることで圧電素子を振動させる。 こ のとき, 圧電素子に生じる変位 $u$ は加振角振動数 $\omega_{P}$ と最 大振幅 $u_{0}$, 位相差 $\theta$ を用いて次式で表される.

$$
u=u_{0} \sin \left(\omega_{P} t+\theta\right)
$$

蓄電を開始して十分に時間が経過した定常状態に扔ける圧 電素子の変位 $u$ と電圧 $V_{P}$ との関係を第 3 図に示す. ここ で, $V_{C 0}$ は定常状態における蓄電コンデンサの電圧を表す. $\left|V_{P}\right|<V_{C 0}$ であるとき, 電流はダイオードブリッジの効果 により蓄電コンデンサ側に流れないため, (1) 式からわかる ように, この間 $V_{P}$ は $u$ に比例して増加する. $\left|V_{P}\right|=V_{C 0}$ となった瞬間からダイオードブリッジを通じて電流が流れ 始め, $u$ が増加を続ける間は $\left|V_{P}\right|=V_{C 0}$ となる。 このと き, 第 2 図より，流れる電流は次式で表される.

$$
I=C_{r} \dot{V}_{C}+\frac{V_{C 0}}{R_{r}}
$$

その後, $u$ の減少に伴ってダイオードの効果により再び電 流が阻害され， $V_{P}$ は第 3 図に示すような変化を繰り返す 




第 3 図 圧電素子の変位と発生電圧の関係

こととなる

(4) 式を $t=t_{i}$ から $t=t_{f}$ まで積分する.

$$
\int_{t_{i}}^{t_{f}} I(t) \mathrm{d} t=\int_{t_{i}}^{t_{f}} C_{r} \dot{V}_{C} \mathrm{~d} t+\int_{t_{i}}^{t_{f}} \frac{V_{C 0}}{R_{r}} \mathrm{~d} t=\frac{T}{2} \frac{V_{C 0}}{R_{r}}
$$

ここで, $T\left(=2 \pi / \omega_{P}\right)$ は加振力の周期を表す. (5) 式を 用いて (1) 式の 2 行目を $t=t_{i}$ から $t=t_{f}$ まで積分する と, 収束蓄電圧 $V_{C 0}$ は次式のように表される14).

$$
V_{C 0}=\frac{\omega_{P} \Theta R_{r}}{\omega_{P} C_{P}^{S} R_{r}+\frac{\pi}{2}} u_{0}
$$

また，圧電素子の回路が開放されている状態において， $u_{0}$ に対する圧電素子の電圧を $V_{P 0}$ とすると, (1) 式の 2 行目 を用いることにより， $V_{C 0}$ と $V_{P 0}$ との関係式が次式で与 えられる。

$$
V_{C 0}=\frac{\omega_{P} C_{P}^{S} R_{r}}{\omega_{P} C_{P}^{S} R_{r}+\frac{\pi}{2}} V_{P 0}
$$

2.1 .2 蓄電速度に関する定式化 本研究で提案する振動 制御方法では，エネルギ回収によって得られる電荷を振動 制御に即時利用するため, 蓄電速度が重要となる。コンデ ンサの蓄電過程における蓄電圧 $V_{C}$ の変化を表す式は, 一 般的に次式で与えられる.

$$
V_{C}(t)=V_{C 0}\left\{1-\exp \left(-\frac{t}{R_{e} C_{r}}\right)\right\}
$$

ここで， $R_{e}$ は回路抵抗を表す，圧電素子によるエネルギ回 収において，上式における $R_{e}$ は次式で近似することがで きる15).

$$
R_{e}=\frac{1}{\omega_{P} C_{P}^{S}}+R_{P}
$$

ここで, $R_{P}$ は圧電素子の内部抵抗を表す，蓄電速度は (8) 式を時間微分することにより得られる. また, 時定数 $\tau$ は 次式で与えられる.

$$
\tau=R_{e} C_{r}=\left(\frac{1}{\omega_{P} C_{P}^{S}}+R_{P}\right) C_{r}
$$

2.2 定電圧源による同調スイッチダンピング11) つづ いて本節では，本研究で提案する制振方法の基礎となる，定 電圧源による同調スイッチダンピング（SSDV）の概要を 述べる. SSDV は外部電源を用いることによって圧電素子 の電極間電圧を増加させ, より大きな減衰効果が得られる ようスイッチを制御して制振を行う方法であり，能動制御 に基づく制振のような複雑な計測・制御系や大きな外部電 源を必要とせず，受動制御に基づく制振と比較してより効 果的な制振が可能となる。初めに，1 自由度系の等価モデ ルを対象として SSDVの概要を説明し，その制振効果を定 式化する。

2.2.1 等価モデルの振動特性 前述した通り, 共振点付 近で線形振動する構造物は, 圧電素子を含め, 第 1 図に示 すような 1 自由度系の等価モデルとして表される。このと き, (1) 式の 1 行目を用いて系の運動方程式は次式で与え られる。

$$
M \ddot{u}+C \dot{u}+\left(K+K_{P E}\right) u+\Theta V_{P}=F
$$

回路開放時は圧電素子に電流が流れないため, 変位 $u$ と外 力 $F$ との関係を表す伝達関数は, 回路短絡時の圧電素子 を含めた構造物全体の剛性を $K_{E}\left(=K+K_{P E}\right)$ とした 場合, 次式で与えられる。

$$
\frac{\tilde{u}}{\tilde{F}}=\frac{1}{K_{E}+\frac{\Theta^{2}}{C_{P}^{S}}-\omega^{2} M+j \omega C}
$$

よって, 回路開放時の共振角振動数 $\omega_{D}$, およびそのとき の加振力の最大值 $F_{M}$ に対する変位の最大值 $u_{M}$ は, そ れぞれ次式で与えられる。

$$
\omega_{D}=\sqrt{\frac{K_{E}+\frac{\Theta^{2}}{C_{P}^{S}}}{M}}, \quad u_{M}=\frac{F_{M}}{\omega_{D} C}
$$

2.2.2 制振効果に関する定式化 SSDVにおいて圧電素 子に接続される電気回路は, 第 4 図に示すように, コイル (インダクタンス值 $L$ ), 抵抗 (抵抗值 $R$ ), 正負の定電圧 源（電圧 $V_{S}$ ), およびスイッチから構成される。(1) 式の 2 行目の圧電方程式を電荷 $Q_{P}$ に関して書き換えると次式 が得られる。

$$
V_{P}=\frac{\Theta}{C_{P}^{S}} u-\frac{1}{C_{P}^{S}} Q_{P}
$$

ここで, (11) 式において比例・微分 (ProportionalDerivative; PD）制御に基づく制振の適用を考えた場合, 上式の $Q_{P}$ に対する外部からの制御入力電荷 $Q_{T}$ は, 微 分ゲイン $\alpha_{T}(>0)$ を用いて次式で与えられる.

$$
Q_{T}=-\alpha_{T} \dot{u}
$$

$\mathrm{SSD}$ では， $Q_{T}$ の值に追従するよう $Q_{P}$ の值を制御する ことによって圧電素子に制振力を発生させ，構造振動の抑 制を図る。すなわち， $Q_{T}>0$ ならば $Q_{P}$ ができるだけ大 きく, $Q_{T}<0$ ならば $Q_{P}$ ができるだけ小さくなるようス 




イッチの切替え操作を行う.

第 1 図に示す 1 自由度系の等価モデルが外力によって定 常振動している場合を考える. 外力 $F$, 拈よび変位 $u$ を, 位相差 $\varphi$ を用いて次式で定義する。

$$
F=F_{M} \sin \omega t, \quad u=u_{M} \sin (\omega t+\varphi)
$$

第 4 図より， $Q_{P}$ の変化は次式で表される.

$$
\begin{array}{ll}
\text { 回路開放時: } & \dot{Q}_{P}=0 \\
\text { 回路短絡時: } & L \ddot{Q}_{P}+R \dot{Q}_{P}=-V_{P} \pm V_{S}
\end{array}
$$

なお，(18) 式における $V_{S}$ の符号は， $\dot{u} \times V_{S}$ が常に負と なるように決定される。(18) 式より，回路を閉じたときに $V_{P}>0$ ならば $Q_{P}$ は減少し, $V_{P}<0$ ならば $Q_{P}$ は増加 することがわかる．よって， $Q_{P}$ の值が $Q_{T}$ の值に追従す るよう $Q_{T} V_{P}>0$ である間は回路を開放して電荷の放出 を防ぐ，この間電荷 $Q_{P}$ の値は変化しないが, 圧電素子の 電圧 $V_{P}$ は (14) 式により変位 $u$ に比例した増加を続ける. $Q_{T} V_{P}<0$ となった瞬間に回路を閉じると, (18) 式の微分 方程式を解くことにより電荷 $Q_{P}$ は次式に従い振動を始め ることがわかる。

$$
\begin{aligned}
& Q_{P}=e^{-\omega_{c} \zeta_{c} t}\left(C_{1} \cos A t+C_{2} \sin A t\right)+Q_{a} \pm C_{P}^{S} V_{S} \\
& A=\omega_{c} \sqrt{1-\zeta_{c}^{2}}, \quad Q_{a}=\Theta u_{M} \\
& \omega_{c}=\sqrt{\frac{1}{L C_{P}^{S}}}, \quad \zeta_{c}=\frac{R}{2 \omega_{c} L}
\end{aligned}
$$

(19) 式に扔いて $\zeta_{c} \ll 1$ とすると, 圧電素子の電荷 $Q_{P}$ は 回路を閉じてから $t$ が $\pi / \omega_{c}$ 経過した後に極值に達し, そ の大きさ $Q_{m}$ は回路を閉じる直前の初期電荷 $Q_{M}$ を用い て次式で表すことができる。

$$
\begin{aligned}
Q_{m}-Q_{a} \mp C_{P}^{S} V_{S} & =-\left(Q_{M}-Q_{a} \mp C_{P}^{S} V_{S}\right) \cdot e^{-\zeta_{c} \pi} \\
& =-\left(Q_{M}-Q_{a} \mp C_{P}^{S} V_{S}\right) \cdot e^{-\frac{\pi}{2 Q_{i}}}
\end{aligned}
$$

ここで, $Q_{i}$ は電気的品質係数を表す，回路を閉じる直前の 圧電素子の電圧を $-V_{M}$, 直後の電圧を $V_{m}$ として符号を 揃えると次式が得られる。

$$
\left(V_{m}-V_{S}\right)=e^{-\frac{\pi}{2 Q_{i}}}\left(V_{M}+V_{S}\right)=\gamma\left(V_{M}+V_{S}\right)
$$

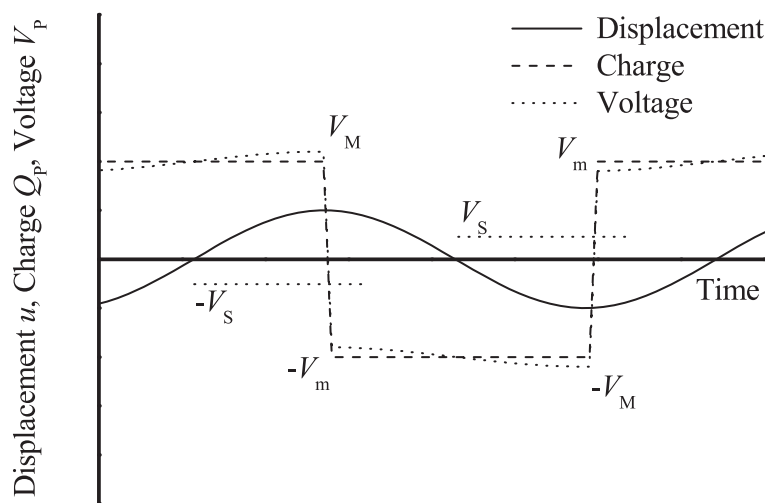

(a) 変位と発生電圧の時間履歴

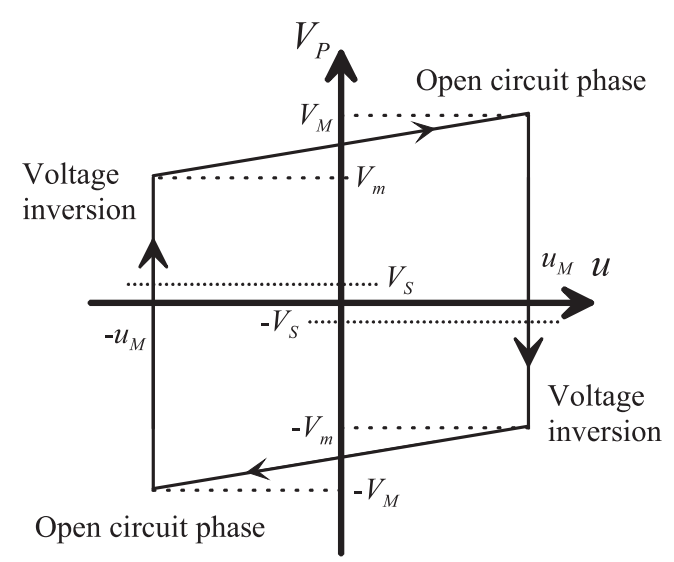

(b) エネルギ・サイクル

第 5 図 スイッチング操作による制振用圧電素子の発生電圧の変化

ここで， $\gamma$ は電圧反転係数を表す，その後回路を開放する ことにより, 再び電圧 $V_{P}$ は変位 $u$ に比例して増加する. (14) 式より， $V_{M}$ と $V_{m}$ との関係は次式のように得られる.

$$
V_{M}=V_{m}+\frac{2 \Theta}{C_{P}^{S}} u_{M}
$$

以上の繰り返しにより, 第 5 図に示すような電圧が圧電素 子に印加され，構造物に対して制振力を作用させることが できる。

(22) 式, および (23) 式より, SSDVに扔いての電圧は 不連続関数 $h$ を用いて次のように表される.

$$
\begin{aligned}
V_{P}= & \frac{\Theta}{C_{P}^{S}}(u+h) \\
h= & \frac{1+\gamma}{1-\gamma}\left(u_{M}+\frac{C_{P}^{S} V_{S}}{\Theta}\right) \operatorname{sign}(\dot{u}) \\
= & \frac{1+\gamma}{1-\gamma}\left(u_{M}+\frac{C_{P}^{S} V_{S}}{\Theta}\right) \sum_{n=0}^{\infty} \frac{4}{\pi(2 n+1)} \\
& \times \cos \{(2 n+1) \omega t+\varphi\}
\end{aligned}
$$

ここで, $\operatorname{sign}(\dot{u})$ は $\dot{u}$ の符号を表す。 よって, (25) 式にお いて 1 次固有振動数のみを考慮する場合, (11) 式に (16) 式，および (24) 式を代入することにより, 運動方程式は次 式で与えられる。 


$$
\begin{aligned}
& u_{M}\left(K_{E}+\frac{\Theta^{2}}{C_{P}^{S}}-\omega^{2} M\right) \sin (\omega t+\varphi) \\
& +\left[u_{M}\left(\omega C+\frac{4 \Theta^{2}}{\pi C_{P}^{S}} \frac{1+\gamma}{1-\gamma}\right)+\frac{4 \Theta}{\pi} \frac{1+\gamma}{1-\gamma} V_{S}\right] \\
& \times \cos (\omega t+\varphi) \\
& \quad=F_{M} \sin \omega t
\end{aligned}
$$

なお， $t=\pi / 2 \omega$ の場合,

$$
\begin{aligned}
& u_{M}\left(K_{E}+\frac{\Theta^{2}}{C_{P}^{S}}-\omega^{2} M\right) \cos \varphi \\
& -\left[u_{M}\left(\omega C+\frac{4 \Theta^{2}}{\pi C_{P}^{S}} \frac{1+\gamma}{1-\gamma}\right)+\frac{4 \Theta}{\pi} \frac{1+\gamma}{1-\gamma} V_{S}\right] \sin \varphi \\
& \quad=F_{M}
\end{aligned}
$$

ここで, 構造物が周期加振力によって共振しているとき, (16) 式に扔いて変位 $u$ と外力 $F$ との位相差 $\varphi$ は $-\pi / 2$ で あることから, SSDVに扮ける加振力の振幅 $F_{M}$ に対する 変位の振幅 $u_{M}$ は, 次式で与えられる.

$$
u_{M}^{\mathrm{SSDV}}=\frac{F_{M}-\frac{4 \Theta}{\pi} \frac{1+\gamma}{1-\gamma} V_{S}}{\omega_{D} C+\frac{4 \Theta^{2}}{\pi C_{P}^{S}} \frac{1+\gamma}{1-\gamma}}
$$

本研究に扔いては, SSDV の制振効果の評価基準として

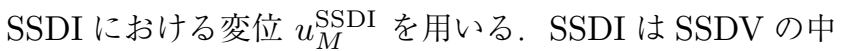
で定電圧源 $V_{S}$ が存在しない特殊な場合であると考えられ, 上式において $V_{S}=0$ とすることで $u_{M}^{\mathrm{SSDI}}$ を定義すること ができる。よって, SSDI に対するSSDV の制振効果 $I_{e}$ は 次式で与えられる.

$$
I_{e}=\frac{u_{M}^{\mathrm{SSI}}-u_{M}^{\mathrm{SSDV}}}{u_{M}^{\mathrm{SSDI}}}=\frac{4 \Theta}{\pi} \frac{1+\gamma}{1-\gamma} \frac{V_{S}}{F_{M}}
$$

上式より, SSDV の制振効果は回路上の定電圧源 $V_{S}$ の大 きさに比例することがわかる.

\section{3. 実験による検証}

本章では, 本研究に扔いて提案する, 圧電エネルギ回収 機による同調スイッチダンピング（SSDP）に基づく振動 制御方法の有効性に関して, 実験による検証を行う。また, 実験結果を通じて，圧電素子のエネルギ回収特性を踏まえ 本提案方法が有する特性に関して検討を行う.

3.1 実験装置 本研究で用いる実験装置の概要を第 6 図 に示す、はりは $[90 /-45 / 45 / 0]_{\mathrm{s}}$ の積層構成を有する CFRP 対称積層板によって構成され, CFRP一方向材の材料定数, および積層板の板厚を第 1 表に示す。ここで, 第 6 図にお いて, 積層板の繊維配向角を $\theta$ を用いて表している。制振 対象となる CFRP 片持はり（第 6 図左）の固定端近傍に 2 個の同一の PZT 圧電素子を貼付し, 一方は加振用（図中 (1)）として，他方は制振用（図中(2) として用いる。回路 開放時の自由端変位が $4 \mathrm{~mm}$ の定常振動となるよう, 加振 用 PZT に対して PC から D/A 変換器とピエゾドライバを 介して片持はりの 1 次固有振動数 $f_{1}(\approx 19.0 \mathrm{~Hz})$ と等し い周波数の正弦波電圧を印加する。また，エネルギ回収に 用いる CFRP 片持はり（第 6 図右）の自由端は加振器に 固定されている.SSDV に扔いては，回路に正負 2 個の定 電圧源が必要となるため, 本実験ではエネルギ回収に用い る片持はりの固定端近傍の表裏にそれぞれ同一のエネルギ 回収用 PZT 圧電素子 (図中(3) を対称に貼付して用いる. PZT 圧電素子の材料定数, および寸法を第 2 表に示す。こ こで, $\varepsilon_{33}^{T}$, および $\varepsilon_{0}$ はそれぞれ, 自由誘電率, および真 空誘電率を表し， $k_{31}$ は電気機械結合係数を表す。また，第 6 図に挍いて, 回路に用いるコイルのインダクタンス值 $L$ は，予備実験において最も高い制振効果を示した $20 \mathrm{mH}$ と した.

第 1 表 CFRP 積層板の材料定数

\begin{tabular}{cccccc}
\hline $\begin{array}{c}E_{11} \\
{[\mathrm{GPa}]}\end{array}$ & $\begin{array}{c}E_{22} \\
{[\mathrm{GPa}]}\end{array}$ & $\begin{array}{c}G_{12} \\
{[\mathrm{GPa}]}\end{array}$ & $\nu_{12}$ & $\begin{array}{c}\rho \\
{\left[\mathrm{kg} / \mathrm{m}^{3}\right]}\end{array}$ & $\begin{array}{c}\text { Thickness } \\
{[\mathrm{mm}]}\end{array}$ \\
\hline 127.0 & 11.0 & 4.9 & 0.30 & 1,541 & 1.0 \\
\hline
\end{tabular}

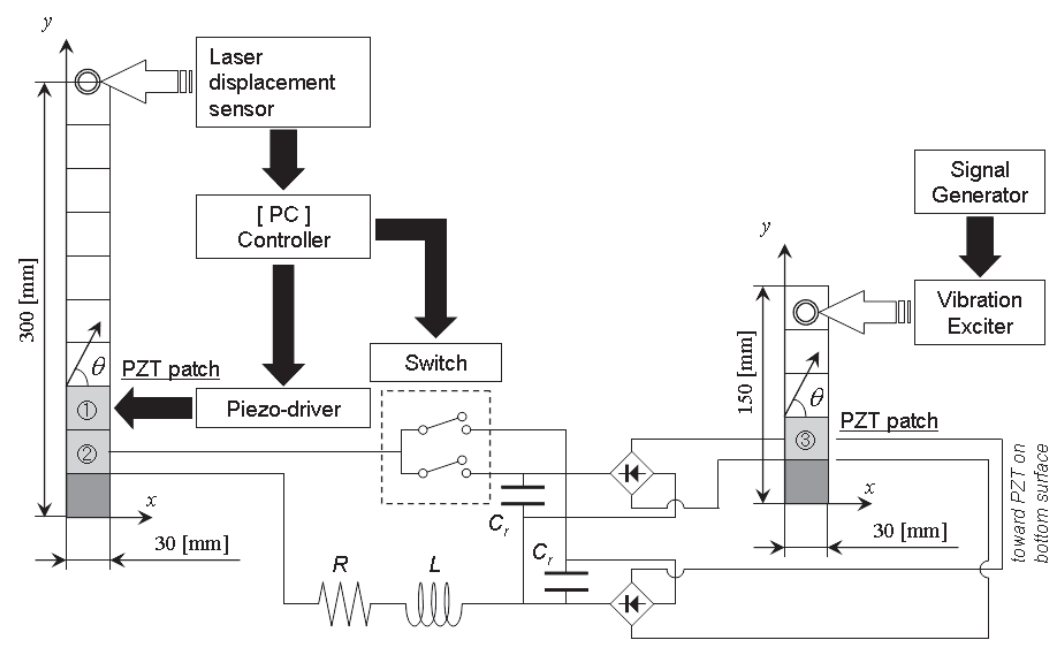

第 6 図 実験装置の概要 
第 2 表 PZT の材料定数

\begin{tabular}{cccccccc}
\hline $\begin{array}{c}E_{11} \\
{[\mathrm{GPa}]}\end{array}$ & $\nu$ & $\begin{array}{c}\rho \\
{\left[\mathrm{kg} / \mathrm{m}^{3}\right]}\end{array}$ & $\begin{array}{c}\text { Thickness } \\
{[\mathrm{mm}]}\end{array}$ & $\begin{array}{c}C_{P}^{S} \\
{[\mathrm{nF}]}\end{array}$ & $\begin{array}{c}d_{31} \\
{[\mathrm{pm} / \mathrm{V}]}\end{array}$ & $\varepsilon_{33}^{T} / \varepsilon_{0}$ & $k_{31}$ \\
\hline 63.0 & 0.30 & 7,800 & 0.25 & 65.0 & -240 & 2,400 & 0.41 \\
\hline
\end{tabular}

第 3 表 等価モデルの物性值

\begin{tabular}{ccccccccc}
\hline $\begin{array}{c}f_{E} \\
{[\mathrm{~Hz}]}\end{array}$ & $\begin{array}{c}f_{D} \\
{[\mathrm{~Hz}]}\end{array}$ & $\xi$ & $\begin{array}{c}\lambda \\
{[\mathrm{kV} / \mathrm{m}]}\end{array}$ & $\begin{array}{c}\Theta \\
{[\mathrm{mN} / \mathrm{V}]}\end{array}$ & $\begin{array}{c}K_{E} \\
{[\mathrm{~N} / \mathrm{m}]}\end{array}$ & $\begin{array}{c}M \\
{[\mathrm{~g}]}\end{array}$ & $\begin{array}{c}C \\
{[\mathrm{~N} \cdot \mathrm{s} / \mathrm{m}]}\end{array}$ & $\gamma$ \\
\hline 18.995 & 19.046 & $5.6 \times 10^{-3}$ & 3.2 & 0.202 & 120.0 & 84.2 & $1.12 \times 10^{-2}$ & 0.50 \\
\hline
\end{tabular}

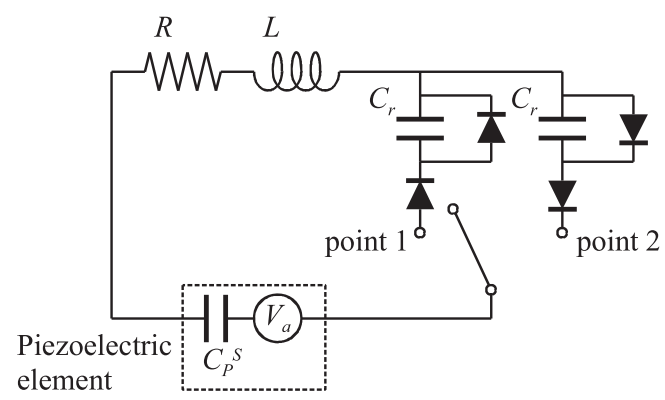

第 7 図 圧電エネルギ回収機による同調スイッチダンピング

本研究では, 第 7 図に示すように, 回路内にダイオード を用いることにより回路切替え装置の簡略化を図る8) とと もに, 2 個の蓄電コンデンサ $C_{r}$ に対してもそれぞれダイ オードを並列に接続している。 これは第 6 図の回路をその まま用いた予備実験において, SSDの方法による回路のス イッチング操作が繰り返される過程で蓄電コンデンサに電 荷が蓄積され，その結果逆符号の電圧が生じ，徐々に制振 効果が低下寸る現象が見られたためである.ダイオードの 接続に伴い抵抗の増加に起因する制振効果の低下が若干見 られるものの, 電荷の蓄積が解消され制振効果の大幅な低 下を防ぐことが可能となる。

一方，圧電素子を含めた等価モデルの運動方程式（(11) 式に打ける各定数は, 次式によって実験的に求められる10).

$$
\begin{aligned}
& \Theta=\lambda C_{P}^{S}, \quad K_{E}=\lambda \Theta \frac{f_{E}^{2}}{f_{D}^{2}-f_{E}^{2}}, \\
& M=\frac{K_{E}}{4 \pi^{2} f_{E}^{2}}, \quad C=4 \pi \xi M f_{D}
\end{aligned}
$$

ここで, $\lambda は$ 回路開放時の自由端変位量と圧電素子出力電 圧の比を表し， $f_{E}$, および $f_{D}$ はそれぞれ, 回路短絡時, および回路開放時の固有振動数, $\xi$ は回路開放時の減衰係 数を表す. 上式を用いて決定した各定数の值を第 3 表に示 す.また，(7) 式に抢ける $R_{r}$ の值は，(7) 式から得られる 計算值と実験值との比較に基づいて $770 \mathrm{k} \Omega$ とし, 同様に (10) 式に打ける $R_{P}$ の值は，(9) 式に基づいて $39.5 \mathrm{k} \Omega$ と した.

3.2 振動制御実験結果 本研究では, SSDP に基づく 制振方法に扔いてエネルギ回収に用いる CFRP 片持はりを 加振器によって定常振動させる際, その加振周波数, エネ ルギ回収用圧電素子の発生電圧の振幅, および蓄電コンデ ンサの静電容量が準能動的制振の制振効果におよぼす影響 に関して検討を行う。
蓄電コンデンサの蓄電圧 $V_{C}$, および制振効果 $I_{e}$ と, エ ネルギ回収用圧電素子の発生電圧の振幅 $V_{P 0}$, 拈よび蓄電 コンデンサの静電容量 $C_{r}\left(\gg C_{P}^{S}\right)$ の関係を第 8 図, およ び第 9 図に示す。第 8 図はエネルギ回収に用いる片持はり の加振周波数を $f_{P}=20 \mathrm{~Hz}$ とした場合, 第 9 図はエネル ギ回収に用いる片持はりの加振周波数を $f_{P}=100 \mathrm{~Hz}$ と した場合について，それぞれ示している。ここで，第 8 図 (a)，抢よび第 9 図 (a) は, エネルギ回収用圧電素子の発生 電圧の振幅 $V_{P 0}$, および蓄電コンデンサの静電容量 $C_{r}$ が 蓄電コンデンサの蓄電圧 $V_{C}$ に拉よぼす影響を示しており, 第 8 図 (b), および第 9 図 (b) は, エネルギ回収用圧電素 子の発生電圧の振幅 $V_{P 0}$, および蓄電コンデンサの静電容 量 $C_{r}$ が制振効果 $I_{e}$ に㧍よぼす影響を示している。 なお, 本研究で提案する SSDP に基づく制振方法の制振効果 $I_{e}$ は, (29) 式と同様に次式で定義している.

$$
I_{e}=\frac{u_{M}^{\mathrm{SSDI}}-u_{M}^{\mathrm{SSDP}}}{u_{M}^{\mathrm{SSDI}}}
$$

これらの図より，提案したSSDP に基づく制振方法はSSDI に基づく制振と比較して制振効果が高く, SSDV に基づく 制振 ${ }^{10)}$ と同様にコンデンサの蓄電圧 $V_{C}$ の増加に比例して 制振効果が向上することがわかる，なお，エネルギ回収用 PZT の発生電圧の振幅 $V_{P 0}$ の増加に伴い蓄電コンデンサ の蓄電圧 $V_{C}$ が増加し, SSDP に基づく制振の制振効果 $I_{e}$ も向上する一方， $V_{P 0}$ の值があるしきい值以上でなければ $I_{e}$ は向上しないことがわかる. また, 第 8 図と第 9 図の比 較により, 加振周波数 $f_{P}$ の増加に伴い, 制振効果が現れ るエネルギ回収用 PZT の発生電圧の振幅 $V_{P 0}$ のしきい值 は小さくなるとともに, 同じ $V_{P 0}$ に対してょり大きな制振 効果が得られることがわかる. また，本検討の範囲内では, エネルギ回収用 $\mathrm{PZT}$ の発生電圧の振幅 $V_{P 0}$ に対する制振 効果 $I_{e}$ の増加量は蓄電コンデンサの静電容量 $C_{r}$ に依存 しないことがわかる。

SSDP に基づく準能動的制振，および従来の SSDV に基 づく準能動的制振の制振効果 $I_{e}$ の比較を第 10 図に示す. この図において，横軸は，SSDP に基づく制振の場合には 蓄電コンデンサの蓄電圧 $V_{C}$ を, SSDV に基づく制振の場 合には定電圧源の電圧 $V_{S}$ を示す。この図より, SSDP に 基づく制振の結果（図中曰, 一, およびム）が第 7 図に示す ように蓄電用コンデンサに直列接続されているダイオード によって順方向降下電圧分シフトしていることを考慮すれ ば，両方法を比較したときに同じ電圧值に対して同程度の 制振効果が得られていることから, 圧電エネルギ回収機は 


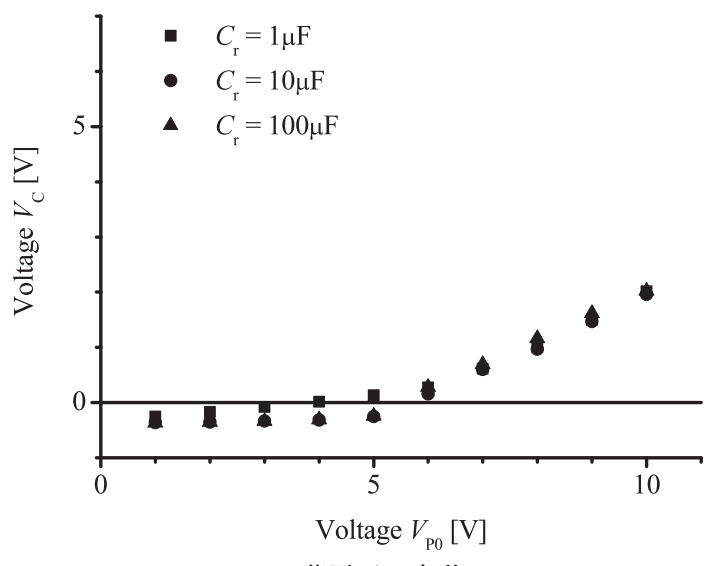

(a) 蓄電圧の変動

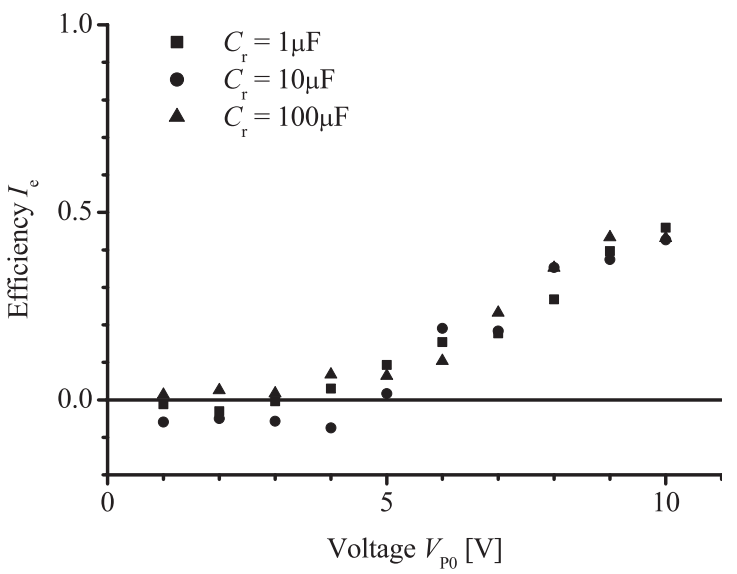

(b) 制振効果の変動

第 8 図 SSDP に基づく制振方法による振動制御結果 $\left(f_{P}=20 \mathrm{~Hz}\right)$

SSDV に基づく制振において用いられる定電圧源の代替と して十分適用可能であることが確認できる.

3.3 制振効果が現れるしきい值に関する考察 前節に おいて述べた通り, 本研究で提案するSSDPに基づく制振 方法の制振効果は，エネルギ回収用 PZT の発生電圧の振 幅 $V_{P 0}$ の值があるしきい值以上でなければ現れない，これ は，蓄電コンデンサの蓄電圧 $V_{C}$ が，エネルギ回収用 $\mathrm{PZT}$ の発生電圧の振幅 $V_{P 0}$ の值がしきい値以上でなければ増加 しないことに起因する。蓄電コンデンサの蓄電圧 $V_{C}$ が増 加し始めるエネルギ回収用 PZT の発生電圧の振幅值のし きい值 $V_{P 0}^{t h}$ とエネルギ回収に用いる片持はりの加振周波数 $f_{P}$ の関倸を第 11 図に示す。この図より, しきい值と加振 周波数の積 $\left(V_{P 0}^{t h} \times f_{P}\right)$ と加振周波数 $f_{P}$ は掞よそ線形関 係にあることがわかる.

蓄電コンデンサの蓄電圧が増加し始めるためには，単位 時間あたりに蓄電コンデンサに流入する電荷量 $Q_{I}$ が流出 する電荷量 $Q_{O}$ より大きくなければならない，単位時間あ たりの電荷の流入による蓄電圧の増加速度 $\dot{V}_{I}$ は $(8)$ 式より 求められ, $t=0$ に扔いて最大值 $\dot{V}_{I M}$ となる, 一方, 単位 時間あたりの電荷の流出による蓄電圧の減少速度 $\dot{V}_{O}$ は制 振対象の片持はりの 1 次固有振動数 $f_{1}$ およびコンデンサ の静電容量 $C_{r}$ を用いることにより与えられ, $Q_{O}=Q_{O m}$ に执いて最小值 $\dot{V}_{O m}$ となる。ここで, $Q_{O m}$ はスイッチン

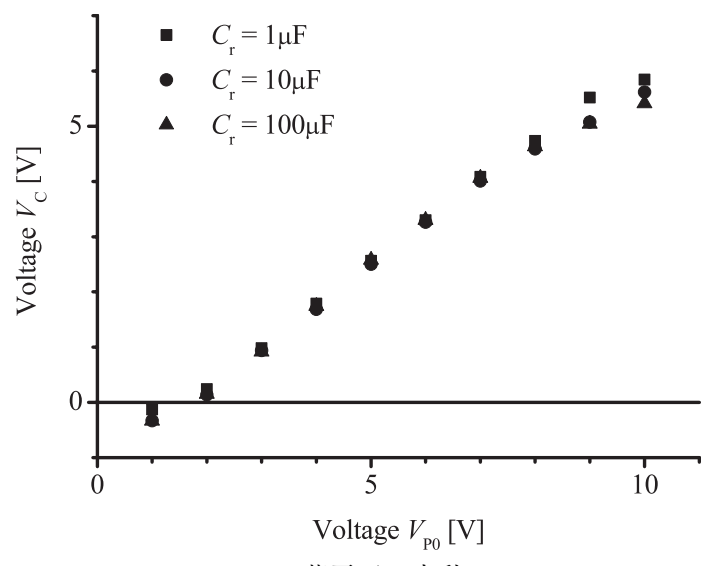

(a) 蓄電圧の変動

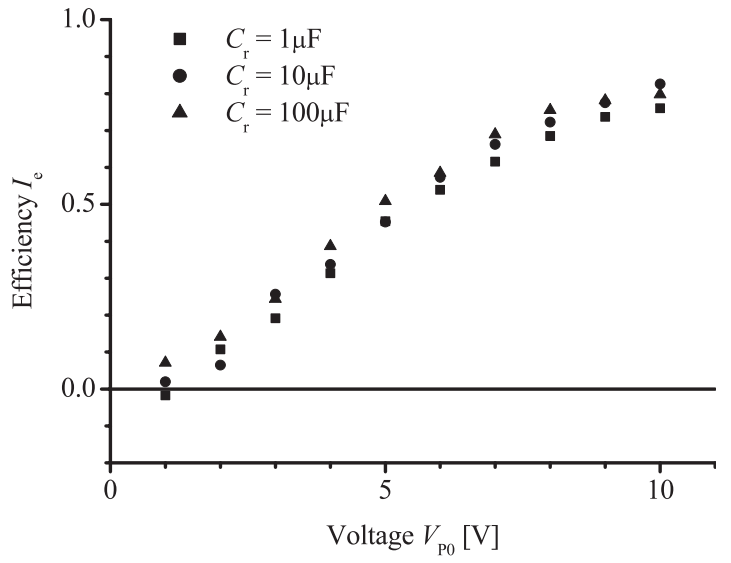

(b) 制振効果の変動

第 9 図 SSDP に基づく制振方法による振動制御結果 $\left(f_{P}=100 \mathrm{~Hz}\right)$

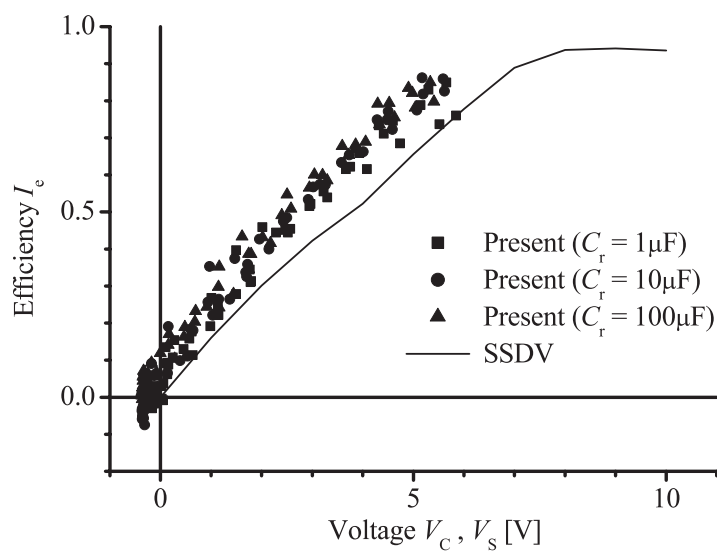

第 10 図 SSDP に基づく制振の制振効果

グ操作によって制振用圧電素子の電圧が反転する際に蓄電 コンデンサから流出する電荷量 $Q_{O}$ の最小值を表す。よっ て, 蓄電コンデンサに電圧が蓄積される条件は次式で与え られる。

$$
\dot{V}_{I M}=V_{C}(0)=\frac{V_{C 0}}{R_{e} C_{r}}>\frac{Q_{O m} f_{1}}{C_{r}}=\dot{V}_{O m}
$$

(9) 式を代入すると,

$$
\left(V_{C 0}-R_{P} Q_{O m} f_{1}\right) \cdot f_{P}>\frac{Q_{O m} f_{1}}{2 \pi C_{P}^{S}}
$$




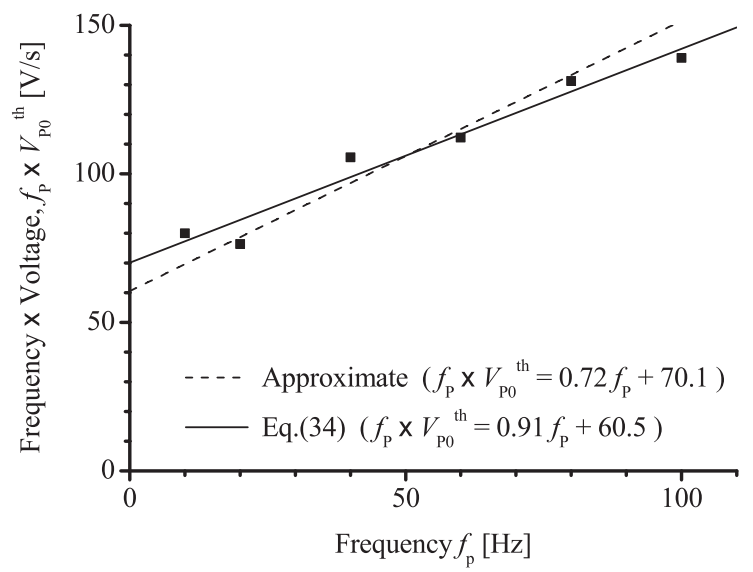

第 11 図 加振周波数が蓄電圧増加のしきい值におよぼす影響

$V_{C 0} \approx V_{P 0}$ とすれば，上式は，

$$
\left(V_{P 0}-R_{P} Q_{O m} f_{1}\right) \cdot f_{P}>\frac{Q_{O m} f_{1}}{2 \pi C_{P}^{S}}
$$

と表される。

本実験条件に打ける各パラメー夕の值を (34) 式に代入す ることにより，本考察に基づいてしきい值を表す関倸式が 得られる。ここで, 式中のスイッチング操作時の流出電荷 量 $Q_{O}$ の最小值 $Q_{O m}$ は, スイッチング操作時の流出電荷 量 $Q_{O}$ と蓄電コンデンサの蓄電圧 $V_{C}$ の関係から実験的に 求められ, 本研究では $1.26 \mu \mathrm{C}$ とした。また, 第 11 図よ り, 実験結果に基づいてしきい值を表す関係式が近似的に 得られる，得られた関係式を第 11 図に併せて示す。この図 より，両者は概ね一致しており，本考察が妥当であること がわかる.

よって, 本研究で提案する SSDP に基づく制振方法には, 制振効果が現れるエネルギ回収用 PZT の発生電圧の振幅 值のしきい值が存在し, そのしきい值は本検討の範囲内で は蓄電コンデンサの静電容量 $C_{r}$ の值に依存しないことが 確認できた。

一方, エネルギ回収用 PZT の発生電圧の振幅 $V_{P 0}$, お よびエネルギ回収に用いる片持はりの加振周波数 $f_{P}$ の値 がしきい值未満の場合, 蓄電コンデンサの蓄電圧 $V_{C}$ の減 少に伴いSSDP に基づく制振方法による制振効果が徐々に 低下し，定常的な制振効果は得られない。工ネルギ回収用 $\mathrm{PZT}$ の発生電圧の振幅を $V_{P 0}=6 \mathrm{~V}$, エネルギ回収用片 持はりの加振周波数を $f_{P}=10 \mathrm{~Hz}$, 蓄電コンデンサの静 電容量を $C_{r}=10 \mu \mathrm{F}$ とした場合について, 制振対象の片 持はりの自由端変位, および蓄電コンデンサの蓄電圧の時 間履歴を第 12 図に示す。この図より，SSDPに基づく制振 方法による制振効果が時間経過に伴い低下していることが わかる。単位時間あたりに減少する蓄電用コンデンサの蓄 電圧 $\dot{V}_{O}$ と増加する蓄電圧 $\dot{V}_{I}$ の差は次式で与えられ, 制 振効果がなくなるまでの時間（持続時間とする）は蓄電コ ンデンサの静電容量に比例することがわかる.

$$
\dot{V}_{O}-\dot{V}_{I}=\frac{1}{C_{r}}\left\{Q_{O} f_{1}-\frac{1}{R_{e}}\left(V_{C 0}-V_{C}\right)\right\}
$$

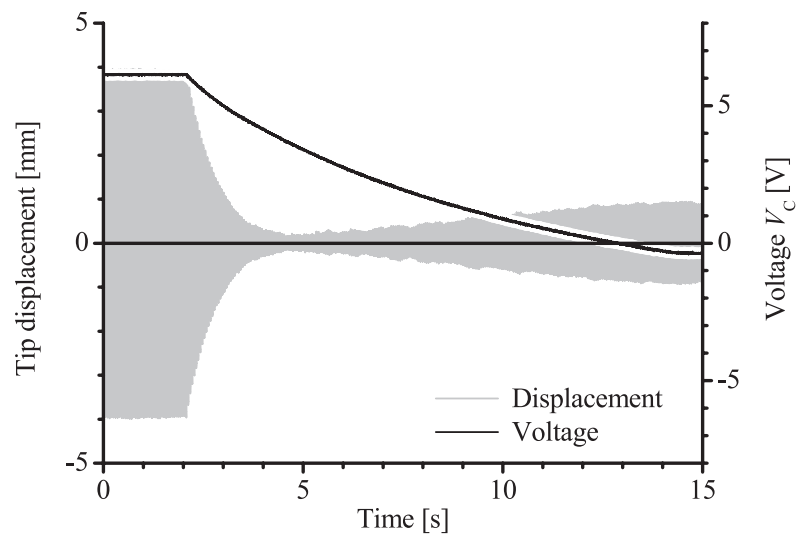

第 12 図 SSDP に基づく制振方法による振動制御結果 $\left(V_{P 0}=6 \mathrm{~V}\right.$, $\left.f_{P}=100 \mathrm{~Hz}, \quad C_{r}=10 \mu \mathrm{F}\right)$

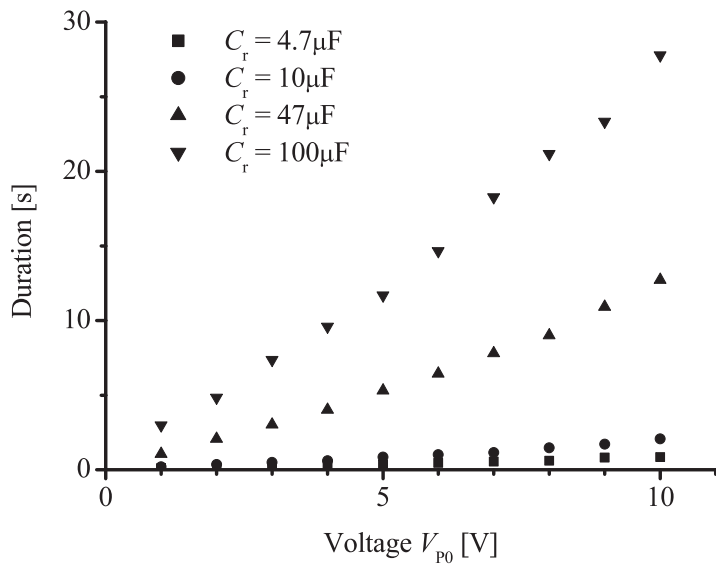

第 13 図 SSDP に基づく制振方法による制振効果の持続性（ $f_{P}=$ $10 \mathrm{~Hz}$ )

エネルギ回収用 $\mathrm{PZT}$ の発生電圧の振幅 $V_{P 0}$, および加 振周波数 $f_{P}$ の值がしきい值未満の場合について, 持続時 間を第 13 図に示す。この図より, 持続時間は蓄電コンデン サの静電容量 $C_{r}$ に比例することがわかる，つまり，本研 究で提案するSSDP に基づく制振方法は，エネルギ回収用 PZT の発生電圧の振幅 $V_{P 0}$, および加振周波数 $f_{P}$ の値 がしきい值未満の場合に扔いても一定の時間は制振効果を 期待できること，また，制振効果が現れる時間は蓄電コン デンサの静電容量 $C_{r}$ が大きいほど長いことがわかる.

\section{4. 結言}

本研究では, SSDVに基づく振動制御における定電圧源 の代替として圧電素子によるエネルギ回収を導入した，圧 電エネルギ回収機による同調スイッチダンピング（SSDP） に基づく振動制御方法を提案した．エネルギ回収，および従 来の SSDV に関する定式化に基づき，定常振動する CFRP 片持はりを対象とした振動制御実験を行い，提案する制振 方法の制振効果，およびその特性に関して検討を行った，実 験結果を通じて，SSDP に基づく制振方法の有効性を確認 し，外部の振動エネルギを制振に即時利用できることを明 らかにした。また，蓄電コンデンサの蓄電圧に比例して制 
振効果も向上し, SSDVにおける同電圧の外部電源を設置 したときと同等の効果が得られることが示された。

なお，本研究で提案するSSDP に基づく制振方法におい て, エネルギ回収に用いる圧電素子の発生電圧の振幅值と 片持はりの加振振動数には制振効果が生じるためのしきい 值が存在し, それらのしきい值を超えなければ定常的な制 振効果の向上が得られないことが明らかとなった。 また，そ れらのしきい值は, 蓄電コンデンサに流出入する電荷量に よって決定され, 蓄電コンデンサの静電容量に依存しない ことを明らかにした。一方，エネルギ回収に用いる圧電素 子の発生電圧の振幅值やエネルギ回収に用いる片持はりの 加振振動数の值がしきい值未満の場合, 制振効果は時間経 過に伴い徐々に低下し，その持続時間は蓄電コンデンサの 静電容量に比例することが確認された。よって, 例えば減 衰振動を対象とする場合には, 大きな静電容量を有するコ ンデンサを用いることによる制振効果の向上が期待できる.

\section{参考 文 献}

1) Ahmadian, M. and DeGuilio, A. P.: Recent Advances in the Use of Piezoceramics for Vibration Suppression, Shock Vib. Digest, 33 (2001), pp. 15-22.

2) Bailey, T. and Hubbard, J. E., Jr.: Distributed PiezoelectricPolymer Active Vibration Control of a Cantilever Beam, J. Guid. Control Dynam., 8 (1985), pp. 605-611.

3) Forward, R. L.: Electronic Damping of Vibrations in Optical Structures, Appl. Opt., 18 (1979), pp. 690-697.

4) Hagood, N. W. and von Flotow, A.: Damping of Structural Vibrations with Piezoelectric Materials and Passive Electrical Networks, J. Sound Vib., 146 (1991), pp. 243-268.

5) Clark, W. W.: Vibration Control with State-Switched Piezoelectric Materials, J. Intell. Mater. Syst. Struct., 11 (2000), pp. 263-271.
6) Richard, C., Guyomar, D., Audigier, D. and Ching, G.: Semi-Passive Damping Using Continuous Switching of a Piezoelectric Device, Proc. SPIE, 3672 (1998), pp. 104-111.

7) Richard, C., Guyomar, D., Audigier, D. and Bassaler, H.: Enhanced Semi-Passive Damping Using Continuous Switching of a Piezoelectric Device on an Inductor, Proc. SPIE, 3989 (2000), pp.288-299.

8) Onoda, J., Makihara, K. and Minesugi, K.: EnergyRecycling Semi-Active Method for Vibration Suppression with Piezoelectric Transducers, AIAA J., 41 (2003), pp. 711719.

9) Lin, Q. and Ermanni, P.: Semi-Active Damping of a Clamped Plate Using PZT, Int. J. Solids Struct., 41 (2004), pp. 1741-1752.

10) Lefeuvre, E., Badel, A., Petit, L., Richard, C. and Guyomar, D.: Semi-Passive Piezoelectric Structural Damping by Synchronized Switching on Voltage Sources, J. Intell. Mater. Syst. Struct., 17 (2006), pp. 653-660.

11) Badel, A., Sebald, D., Guyomar, D., Lallart, M., Lefeuvre, E., Richard, C. and Qiu, J.: Piezoelectric Vibration Control by Synchronized Switching on Adaptive Voltage Sources: Towards Wideband Semi-Active Damping, J. Acoust. Soc. Am., 119 (2006), pp. 2815-2825.

12) Ji, H., Qiu, J., Badel, A. and Zhu, K.: Semi-Active Vibration Control of a Composite Beam Using an Adaptive SSDV Approach, J. Intell. Mater. Syst. Struct., 20 (2009), pp. 401412.

13) Badel, A., Guyomar, D., Lefeuvre, E. and Richard, C.: Efficiency Enhancement of a Piezoelectric Energy Harvesting Device in Pulsed Operation by Synchronous Charge Inversion, J. Intell. Mater. Syst. Struct., 16 (2005), pp. 889-901.

14) Shu, Y. C. and Lien, I. C.: Efficiency of Energy Conversion for a Piezoelectric Power Harvesting System, J. Micromech. Microeng., 16 (2006), pp. 2429-2438.

15) Ng, T. H. and Liao, W. H.: Sensitivity Analysis and Energy Harvesting for a Self-Powered Piezoelectric Sensor, J. Intell. Mater. Syst. Struct., 16 (2005), pp. 785-797. 